\title{
The Expression of Omental 11 $\beta$-HSD1 Is Not Increased in Severely Obese Women with Metabolic Syndrome
}

\author{
Marina Michalaki ${ }^{a}$ Venetsana Kyriazopoulou ${ }^{a}$ Anna Antonacopoulou ${ }^{a}$ \\ Vasiliki Koika $^{a}$ Marinos Nikolaou $^{a}$ Athanasios Tsoukas $^{a}$ \\ Fotis Kalfarentzos $^{b}$ Apostolos G. Vagenakis ${ }^{b}$ Georgia Voukelatou $^{c}$ \\ Athanasios G. Papavassiliou ${ }^{d}$ \\ ${ }^{a}$ Endocrine Division, Department of Internal Medicine, ${ }^{b}$ Division of Nutritional Support \\ and Morbid Obesity, Department of Surgery, 'Department of Physiology, Medical School, \\ University of Patras, Patras, ${ }^{\mathrm{d}}$ Department of Biological Chemistry, Medical School, \\ University of Athens, Athens, Greece
}

\section{Key Words}

Metabolic syndrome $\cdot$ Obesity $\cdot$ Cortisol $\cdot 11 \beta-H S D 1 \cdot G R \alpha \cdot$ Omental adipose tissue $\cdot$ Subcutaneous adipose tissue

\begin{abstract}
Objective: Plasma cortisol in obese subjects does not differ from that in normoweight subjects. Extra-adrenal cortisol production by $11 \beta$-hydroxysteroid dehydrogenase type 1 (11 -HSD1) can result in local hypercortisolemia. The aim of the present study was to examine the role of visceral hypercortisolemia in the development of metabolic syndrome in severe obesity. Methods: Eight lean women during hysterectomy (controls) and 19 severely obese women during bariatric surgery were studied, 8 without metabolic syndrome (OM-group) and 11 with it (OM+ group). Biopsies of omental and subcutaneous fat were performed in the severely obese women during surgery, but only omental biopsies in the controls. Expression of $11 \beta-H S D 1$, glucocorticoid receptor $\alpha(G R \alpha)$ and glucocorticoid receptor $\beta(G R \beta)$ was evaluated using realtime PCR. Results: Omental 11 $\beta$-HSD1 expression was different between groups (one-way ANOVA, $p<0.01$ ). Post-hoc analysis revealed that mean omental $11 \beta-H S D 1$ mRNA levels were higher in the OM-group compared to controls, whereas they were similar when comparing the $\mathrm{OM}+$ group with lean controls. Expression of $11 \beta-\mathrm{HSD} 1$ in subcutaneous fat was not different between $\mathrm{OM}+$ and $\mathrm{OM}-$ groups. GR $\alpha$ expression in omental fat did not differ among groups or between omental and subcutaneous fat in severely obese patients. An expression of GR $\beta$ was not detected. Conclusion: Contrary to our original hypothesis, omental 11ß-HSD1 expression is not increased in the $\mathrm{OM}+$ group.




\section{Introduction}

Obesity is a worldwide epidemic disease whose prevalence is increasing; it is accompanied by many co-morbidities. Abdominal obesity is associated closely with insulin resistance and metabolic syndrome (MetS); however, the molecular mechanisms that underlie this relationship remain elusive. There are many features that are shared between MetS and Cushing's syndrome, which raises the possibility that cortisol plays a key role in both [1]. Clinical and subclinical Cushing's syndrome is characterized by abdominal obesity, high levels of triglycerides, low levels of high density lipoprotein (HDL) cholesterol, arterial hypertension, insulin resistance, glucose intolerance, and in some cases overt diabetes [1]. In excess, glucocorticoids induce hyperglycemia by increasing glycogen storage and gluconeogenesis in the liver and by decreasing glucose uptake and utilization in peripheral tissues [2]. However, plasma cortisol levels in obese patients do not differ from, and may even be lower than, those in people of normal weight $[1,3,4]$. In obesity, the hypothalamic-pituitaryadrenal (HPA) axis is hyper-responsive to several stimuli, such as corticotrophin-releasing hormone (CRH) [5], either alone or in combination with arginine vasopressin (AVP) [6, 7], as well as to hypoglycemia, acute stress, and a standard meal [8]. This is accompanied by elevated metabolic clearance of cortisol $[1,5,8]$, which results in normal circulating levels of cortisol. In some studies, subjects with features of MetS had circulating cortisol levels that were elevated slightly but were lower than those of patients with Cushing's syndrome [9, $10]$.

Extra-adrenal production of cortisol by the enzyme 11 $\beta$-hydroxysteroid dehydrogenase type 1 (11 $\beta$-HSD1) can result in high local levels of cortisol [8]. Intracellular interconversion of inactive cortisone to active cortisol is regulated by the activity of the two isoforms of

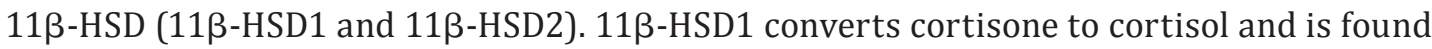
in many tissues, including liver, adipose tissue, muscle, brain and vasculature, whereas $11 \beta$ HSD2 converts cortisol to cortisone and is found in aldosterone-sensitive tissues [8]. This interconversion modulates the actions of glucocorticoids at the pre-receptor level. Studies in transgenic mice have demonstrated that overexpression of 11 $\beta$-HSD1 selectively in adipose tissue results in visceral obesity, hyperlipidemia, and insulin-resistant diabetes mellitus [11]. In contrast, mice in which the gene for 11ß-HSD1 has been disrupted are protected from hyperglycemia, insulin resistance, and dyslipidemia that are induced by obesity and are resistant to visceral obesity when exposed to high-fat diets [12-14]. However, in humans the relation of obesity, insulin resistance, and diabetes type 2 with the expression and activity of $11 \beta$-HSD1 in visceral and subcutaneous adipose tissue, liver, and muscle is more controversial [3]. Most of the human studies in euglycemic obesity have shown that, compared to lean controls, the enzyme expression and activity in adipose tissue is increased while it is decreased in the liver. This down-regulation of $11 \beta$-HSD1 in liver probably is defective in diabetic subjects [3]. Only few studies have examined the correlation of expression and activity of 11 $\beta$-HSD1 from visceral adipose tissue biopsies with indices of insulin resistance showing rather inconclusive results $[15,16]$.

Increased exposure of adipose tissue to glucocorticoids depends not only on local enzymatic conversion of cortisone to cortisol but also on the abundance of glucocorticoid receptors (GRs) in the tissue. There are two isoforms of the GR, GR $\alpha$ and GR $\beta$, which are splice variants of the same gene [17]. GR $\alpha$ is the active receptor, whereas GR $\beta$ is unable to bind the ligand and is considered to be a negative regulator of glucocorticoid action. Cortisol induces down-regulation of GR $\alpha$ and up-regulation of GR $\beta$ [18]. Few studies have examined the expression of GR $\alpha$ in omental and subcutaneous adipose tissue, and they have reported conflicting results [19-21]. 
Our hypothesis is that local hypercortisolemia in visceral adipose tissue links obesity with its metabolic consequences. To investigate this hypothesis, we examined the expression of $11 \beta$-HSD1, together with that of GR $\alpha$ and GR $\beta$, in omental and subcutaneous adipose tissue in severely obese patients with or without MetS, and compared them with healthy lean matched controls.

\section{Patients and Methods}

Patients

We studied 27 women who underwent elective surgery prospectively. All participants underwent a complete clinical, biochemical and endocrine work-up before surgery, which included an oral glucose tolerance test (OGTT) with $75 \mathrm{~g}$ of glucose and measurement of baseline cortisol and fasting insulin. Women with dyslipidemia, diabetes or pre-diabetes, hypertension, any endocrine abnormality, or cancer were excluded. Eight women (mean age $41.4 \pm 6.8$ years) who were of normal weight (BMI $23 \pm 2.3 \mathrm{~kg} /$ $\mathrm{m}^{2}$ ) underwent hysterectomy, some with oophorectomy, owing to menorrhagia/menometrorrhagia or myoma/fibroids (controls). The remaining 19 women studied were severely obese and underwent bariatric surgery. Of these, 8 women (mean age $35.3 \pm 9.1$ years, BMI $52.9 \pm 8.9 \mathrm{~kg} / \mathrm{m}^{2}$ ) did not have MetS, diabetes or any endocrine abnormality (designated $\mathrm{OM}-$ ), whereas 11 women (mean age $35.8 \pm 12.3$ years, BMI $57.9 \pm 8 \mathrm{~kg} / \mathrm{m}^{2}$ ) had MetS, as defined by IDF criteria [22], and were designated OM+. Two patients from group $\mathrm{OM}+$ had diabetes mellitus type 2 and received metformin at a dose of 1,700 mg/day. None of the patients received any medication known to interfere with the regulation of 11 $\beta$-HSD1. Insulin resistance was estimated by the homeostasis model for assessment of insulin resistance (HOMA-IR) using the formula: insulin $(\mu \mathrm{IU} / \mathrm{ml}) \times$ fasting plasma glucose $(\mathrm{mmol} / \mathrm{l}) / 22.5$ [23]. Body composition was estimated by bioelectrical impendence (BC-418 Segmental Body Composition Analyzer; Tanita Europe B.V., Amsterdam, The Netherlands, UK). Informed consent was obtained from all patients and the protocol was approved by the ethical committee of the University Hospital, University of Patras Medical School.

\section{Biochemical Measurements}

Glucose, urea, creatinine, electrolytes, cholesterol, triglycerides, and liver chemistry were measured by enzymatic colorimetric assay employing an automated clinical chemistry analyzer. Serum cortisol and insulin were measured by chemiluminescence immunoassays (Modular Analytics E170; Roche Diagnostics, Indianapolis, IN, USA). The intra-assay coefficient of variation was $1.9-2 \%$ for insulin and $1.7 \%$ for cortisol, and the inter-assay coefficient of variation was $2.5-2.6 \%$ for insulin and $1.8-2.2 \%$ for cortisol.

\section{Adipose Tissue Sampling}

During surgery, omental biopsies were obtained from all participants during the first 30 min after the skin incision; as well as subcutaneous abdominal biopsies from 7 patients from $\mathrm{OM}-$ and $\mathrm{OM}+$ group. The samples were frozen immediately in liquid nitrogen and carried to the laboratory for storage at $-80^{\circ} \mathrm{C}$.

\section{RNA Extraction and Reverse Transcription}

Total RNA was extracted from $100 \mathrm{mg}$ of omental and $100 \mathrm{mg}$ of subcutaneous adipose tissue (RNeasy Lipid Tissue Kit; Qiagen, Hilden, Germany). The samples were incubated with DNAase (Ambion, Austin, TX, USA) and then quantified using the fluorescent dye RiboGreen (Molecular Probes, Leiden, The Netherlands) and a MX3000p Real-Time (RT) PCR System (Stratagene, La Jolla, CA, USA) according to the manufacturers' instructions. The integrity of the RNA was assessed by electrophoresis on 1\% (w/v) agarose gels, and the quantity was determined spectrophotometrically at $260 \mathrm{~nm}$. A total of $0.1 \mu \mathrm{g}$ of RNA was transcribed into cDNA and stored at $-80^{\circ} \mathrm{C}$ until RT PCR was performed (Qiagen).

\section{RT PCR for $11 \beta$-HSD1 and GR $\alpha / \beta$}

The levels of expression of $11 \beta$-HSD1, Gr $\alpha, \mathrm{GR} \beta$, and TATA box-binding protein (TBP) were quantified using the intercalating dye SYBR Green I in a Precision MasterMix (PrimerDesign, Southampton, UK) and the following gene-specific primers: Gr $\alpha$ forward: ACCACCAGTGCCCAAAG, Gr $\alpha$ reverse: TTTCATCCAGCCAACTGTG; GR $\beta$ forward: CAGCGGTTTTATCAACTGAC, GR $\beta$ reverse: TGTGAGATGTGCTTTCTGG; $11 \beta$ - 
Table 1. Characteristics of severely obese women

\begin{tabular}{llll}
\hline & OM- $(\mathrm{n}=8)$ & $\mathrm{OM}+(\mathrm{n}=11)$ & $\mathrm{p}$ value \\
\hline Age, years & $35.3 \pm 9.1$ & $35.8 \pm 12.3$ & n.s. \\
BMI, kg/m² & $52.9 \pm 8.9$ & $57.9 \pm 8$ & n.s. \\
Fat mass, kg & $75.5 \pm 19.7$ & $77.4 \pm 15.5$ & n.s. \\
Cortisol, $\mu \mathrm{g} / \mathrm{dl}$ & $14.5 \pm 6.8$ & $15.4 \pm 5.7$ & n.s. \\
GOT, IU/l & $20.8 \pm 5.7$ & $30.3 \pm 18.9$ & n.s. \\
GPT, IU/l & $29 \pm 5.1$ & $26.7 \pm 16.9$ & n.s. \\
$\gamma$ GT, IU/l & $22.4 \pm 9$ & $32.9 \pm 17.7$ & n.s. \\
Triglycerides, mg/dl & $106.2 \pm 17.3$ & $157.2 \pm 56$ & $<0.05$ \\
HDL, mg/dl & $45.5 \pm 5.3$ & $41.4 \pm 9.9$ & n.s. \\
Glucose, mg/dl & $89.5 \pm 10.6$ & $130.4 \pm 40.6$ & $<0.01$ \\
HOMA-IR & $2.98 \pm 1$ & $8.57 \pm 6.5$ & $<0.05$ \\
\hline
\end{tabular}

HSD1 forward: AGCATTGTTGTCGTCTCCTC, 11ß-HSD1 reverse: GAACCCATCCAAAGCAAAC; TBP forward: AAAGACCATTGCACTTCGTG, TBP reverse: GGTTCGTGGCTCTCTTATCC). All primers were synthesized by Metabion (Martinsried, Germany). The reactions contained 5-carboxy-X-rhodamine (ROX) as a passive reference dye and cDNA equivalent to $100 \mathrm{ng}$ of total RNA. The PCR was performed in triplicate using an MX3000p RT PCR System (Stratagene). The results were analyzed using the LinRegPCR analysis program. The mRNA levels of Gr $\alpha, G R \beta$, and 11 $\beta$-HSD1 were normalized to the level of TBP, which has been shown previously to be a suitable reference gene [24].

\section{Statistical Analyses}

All values are expressed as the mean \pm SD and statistical significance was set at $p<0.05$. The normality of variables was examined by one-sample Kolmogorov-Smirnov tests. Mean values were compared among groups by one-way ANOVA and post hoc analysis using the Bonferroni test, or independent-samples t-tests. Pearson correlations coefficients were performed to quantify associations. The data were analyzed using SPSS version 17 (SPSS, Inc., Chicago, IL, USA).

\section{Results}

All participants were of a similar age. BMI and fat mass were also similar between the two groups of severely obese women (table 1). The biochemical parameters GOT, GPT, $\gamma$ GT, and HDL did not differ between the $\mathrm{OM}-$ and $\mathrm{OM}+$ subjects, whereas the levels of glucose, triglycerides and HOMA-IR were higher in the OM+ group ( $<<0.01-0.05)$ (table 1). All subjects were euthyroid and the baseline cortisol levels were comparable between the OMand $\mathrm{OM}+$ groups.

The expression of omental 11 $\beta$-HSD1 was different among the three groups (one-way ANOVA; controls $27.8 \pm 16, \mathrm{OM}-107.2 \pm 77.7, \mathrm{OM}+62.9 \pm 24.4 ; \mathrm{p}<0.01$ ) (fig. 1). Post hoc analysis by Bonferroni test, revealed that mean omental 11 $\beta$-HSD1 mRNA levels were higher in OM- subjects than lean controls $(\mathrm{p}<0.01)$, whereas mean omental 11ß-HSD1 mRNA levels in OM+ group were similar compared to controls ( $p=0.33)$ and OM-group ( $p=0.143)$. Moreover, omental 11 $\beta$-HSD1 mRNA levels in severely obese women with or without MetS were not correlated with HOMA-IR $(r=0.24 ; \mathrm{p}=0.354)$, triglycerides $(\mathrm{r}=0.299 ; \mathrm{p}=0.213)$, or fasting glucose $(r=0.066, \mathrm{p}=0.788)$.

The expression of $11 \beta-H S D 1$ in subcutaneous fat was not different between the OMand $\mathrm{OM}+$ group $(\mathrm{OM}-155.9 \pm 124.9$ vs. $\mathrm{OM}+86.5 \pm 29.8$; independent $\mathrm{t}$-test, $\mathrm{p}=0.198)$. The expression of $11 \beta-H S D 1$ did not differ significantly between subcutaneous and omental fat in $0 M-(p=0.374)$. and $O M+$ patients $(p=0.085)$. 


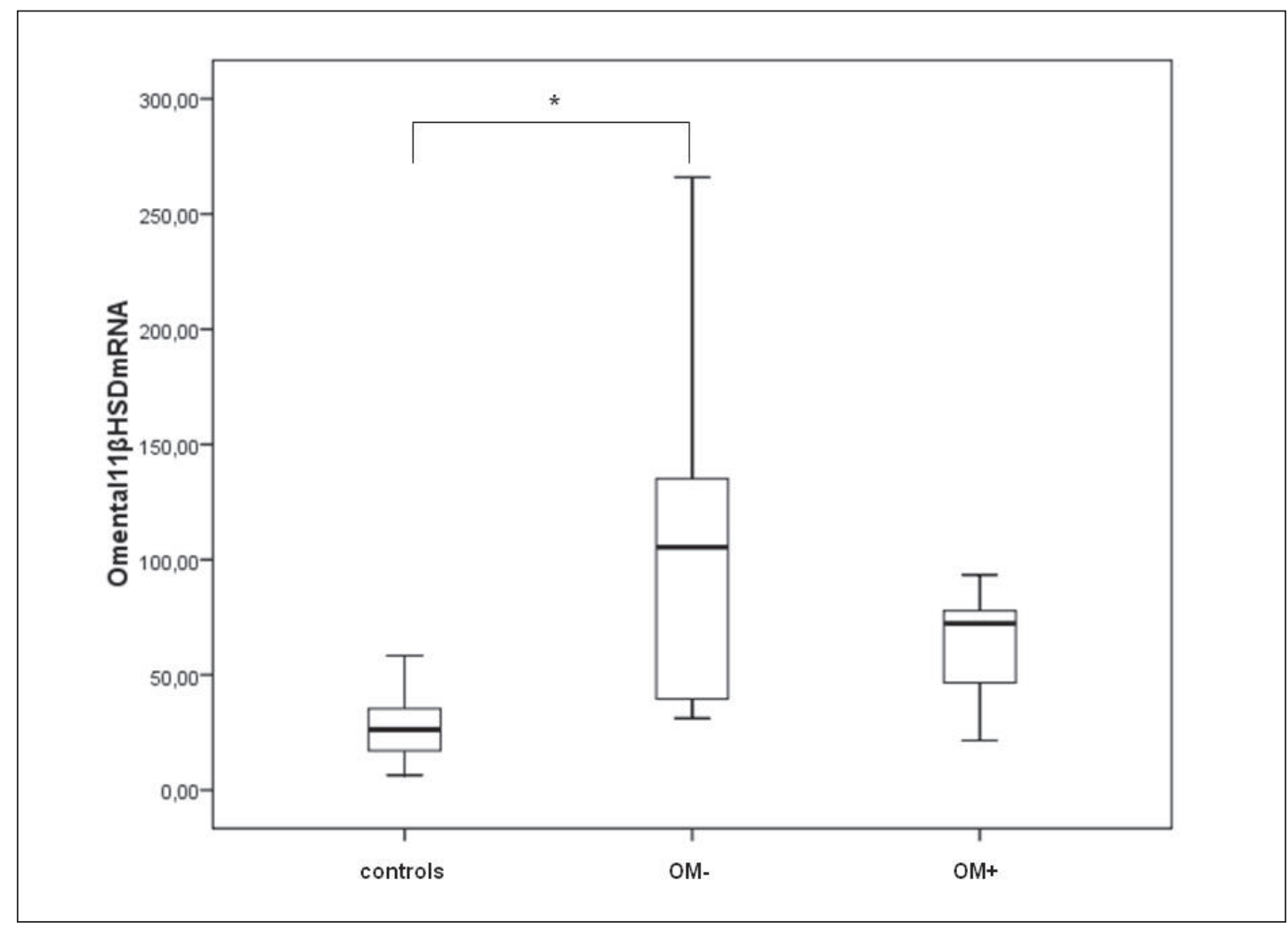

Fig. 1. Box-plots of omental 11 $3-H S D 1$ mRNA levels in OM-, OM+ and control subjects. One-way ANOVA (p $<0.01$ ) and post hoc analysis revealed that omental 11 $\beta$-HSD1 expression was similar between OM+ and $\mathrm{OM}$ - and control subjects, whereas it was higher in OM- group compared to controls $(\mathrm{p}<0.01)$.

The levels of GR $\alpha$ mRNA were similar in omental fat in the three groups (one-way ANOVA, n.s.). The expression of GR $\alpha$ did not differ between omental and subcutaneous fat in severely obese patients with or without MetS. The expression of GR $\beta$ was not detected in either omental or subcutaneous fat in any of the groups.

\section{Discussion}

In contrast to our initial hypothesis, we found that the expression of the enzyme 11ßHSD1 in omental fat was not increased in severely obese women with MetS compared to those without MetS and healthy lean women. At the same time, the expression of GR $\alpha$ was similar among the three groups as well as in omental and subcutaneous adipose tissue in severely obese women.

Few studies in the literature have investigated the expression of $11 \beta-H S D 1$ in visceral fat. The expression of omental 11 $\beta$-HSD1 is increased in obese patients in some reports [15, $19,20,25-28$ ] but not in all [29]. From these studies only Veilleux et al. [15] have examined the correlation of the activity and expression of omental 11 $\beta$-HSD1 with metabolic parameters. They found that women in the highest tertile of omental 11ß-HSD1 activity had higher omental lipolysis, lower levels of HDL, lower levels of adiponectin, and higher insulin resistance than women in the lowest tertile. In the same study, after a logarithmic transformation of the measurements of the activity of the enzyme, a positive association was 
observed between the enzyme activity and HOMA-IR. In another study, the visceral adipose tissue 11ß-HSD1 expression was associated with glucose and insulin levels, in morbidly obese patients [30]. In accordance with our data, another study [16] which included 49 severely obese patients showed that the levels of visceral 11 $\beta$-HSD1 mRNA did not differ

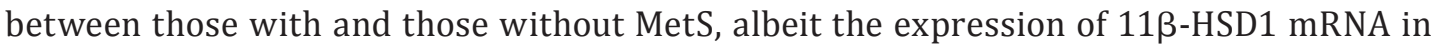
visceral fat correlated with fasting plasma insulin. Also, the splanchnic cortisol production did not differ among lean nondiabetics and obese subjects with or without diabetes [31] and did not correlate with either visceral fat or endogenous glucose production. Moreover, no difference in $11 \beta$-HSD1 activity was found between obese participants with or without type 2 diabetes as estimated by glucocorticoid metabolites in urine [32]. The aforementioned data are inconclusive. The variable findings among studies could be attributed to methodological differences and different populations selected.

We also found that the omental $11 \beta$-HSD1 gene expression in severely obese women without MetS is higher than that in lean controls, whereas the expression of the enzyme in severely obese women with MetS was not significantly different. The explanation of this finding is not readily apparent. It seems that there is a down-regulation of the enzyme expression in severely obese women with MetS. The transcriptional control of the 11ß-HSD1 gene is highly complicated and governed by a complex molecular network [33]. In vitro,

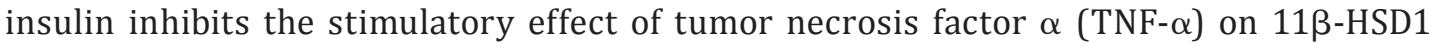
activity in human adipose stromal cells in a dose-dependent manner [34]. Severely obese patients with MetS are more insulin-resistant than those without MetS, as indicated by their higher HOMA-IR index. Possibly the higher insulin levels in OM+ subjects contributes to the down-regulation of the enzyme expression, counteracting the stimulatory effect of TNF- $\alpha$ in this population.

The data regarding the association of the expression of 11 $\beta$-HSD1 gene in subcutaneous fat with fat mass and indices of insulin resistance are also conflicting. Tomlinson et al. [35] have found that in obese women the subcutaneous 11 $\beta$-HSD1 mRNA levels are increased in those with impaired glucose tolerance and correlated with the glucose levels across the OGTT, but independent of fat mass. However, in the same study this observation is not confirmed in obese men. In another study [36], subcutaneous 11ß-HSD1 gene activity is associated with BMI and log fasting insulin, whereas the 11 $\beta$-HSD1 expression is associated with BMI alone.

We did not observe any difference in the levels of 11ß-HSD1 mRNA between omental and subcutaneous fat in severely obese patients with or without MetS. Most of the studies in the literature do not report any difference between ometal and subcutaneous fat expression of 11ß-HSD1 gene [15, 26-29], though in some studies of obesity the expression of $11 \beta$-HSD1 appears to be higher in omental than in subcutaneous fat [1] or higher in subcutaneous than in omental fat [20,31]. In a separate study [25], when the stromal and adipocyte compartments of adipose tissue were examined in obese patients, it was found that the level of $11 \beta$-HSD1 mRNA was higher in the stromal compartment of visceral than in that of subcutaneous fat, whereas it did not differ between the two in the adipocyte compartment.

In our study we did not find any difference in the expression of GR $\alpha$ in visceral adipose tissue among the three groups, or between expression in visceral adipose tissue and subcutaneous adipose tissue in severely obese patients with or without MetS. In addition, we did not detect GR $\beta$ in adipose tissue. There are few reports concerning the role of GRs in adipose tissue in the development of obesity and insulin resistance. Some found that omental expression of GR $\alpha$ did not differ between obese and non-obese controls [20, 21], whereas others have shown that the levels of omental GR $\alpha$ mRNA were inversely associated with visceral adiposity [19]. Additionally, the level of GR $\alpha$ expression was similar in subcutaneous and visceral fat depots in obese subjects [20]. 
One limitation of our study is that we did not examine the activity of the enzyme; however, it seems that the expression of $11 \beta-H S D 1$ is correlated strongly with its activity $[15,36]$. Another limitation is the small sample size. For this reason we estimated what differences in mean values of the expression of omental 11 $\beta$-HSD1 can be identified as significant, maintaining a relatively high power (85\%) of the study. We found that a difference of 32.85 and 26.7 could be identified as significant at the 0.01 or 0.05 level for the means.

From our data, we cannot exclude the hypothesis that local visceral or subcutaneous adipose hypercortisolemia is implicated in the development of insulin resistance and MetS in obesity. Other factors could play a role, e.g. polymorphisms of GR $\alpha$, or other molecules or processes could interfere with cellular glucocorticoid signaling system [37].

Therefore, we failed to reproduce the data from transgenic mice with either disruption of the $11 \beta$-HSD1 gene or overexpressing $11 \beta$-HSD1 gene selectively in adipose tissue in humans. We note here that the relatively small sample size in our study constitutes a limitation; it is sufficient, however, for statistical processing taking also into account the inherent difficulty of these analyses in humans. Nevertheless, we pose that the down-regulation of omental 11 $\beta$-HSD1 might be a counter-regulatory mechanism that protects individuals from the metabolic consequences of obesity.

\section{Disclosure Statement}

The authors declare no conflicts of interest.

\section{References}

1 Anagnostis P, Athyros VG, Tziomalos K, Karagiannis A, Mikhailidis DP: Clinical review: the pathogenetic role of cortisol in the metabolic syndrome: a hypothesis. J Clin Endocrinol Metab 2009;94:2692-2701.

2 White P: Corticosteroid Action; in Becker KL (eds): Principles and Practice of Endocrinology and Metabolism. Philadelphia, Lippincott Williams and Wilkins, 2001, pp 714-719.

- 3 Cooper MS, Stewart PM: 11beta-hydroxysteroid dehydrogenase type 1 and its role in the hypothalamuspituitary-adrenal axis, metabolic syndrome, and inflammation. J Clin Endocrinol Metab 2009;94:4645-4654.

- 4 Pasquali R, Ambrosi B, Armanini D, Cavagnini F, Uberti ED, Del Rio G, de Pergola G, Maccario M, Mantero F, Marugo M, Rotella CM, Vettor R: Cortisol and ACTH response to oral dexamethasone in obesity and effects of sex, body fat distribution, and dexamethasone concentrations: a dose-response study. J Clin Endocrinol Metab 2002;87:166-175.

5 Rask E, Walker BR, Soderberg S, Livingstone DE, Eliasson M, Johnson O, Andrew R, Olsson T: Tissue-specific changes in peripheral cortisol metabolism in obese women: increased adipose 11beta-hydroxysteroid dehydrogenase type 1 activity. J Clin Endocrinol Metab 2002;87:3330-3336.

6 Vicennati V, Ceroni L, Genghini S, Patton L, Pagotto U, Pasquali R: Sex difference in the relationship between the hypothalamic-pituitary-adrenal axis and sex hormones in obesity. Obesity (Silver Spring) 2006;14: 235-243.

- 7 Pasquali R, Gagliardi L, Vicennati V, Gambineri A, Colitta D, Ceroni L, Casimirri F: ACTH and cortisol response to combined corticotropin releasing hormone-arginine vasopressin stimulation in obese males and its relationship to body weight, fat distribution and parameters of the metabolic syndrome. Int J Obes Relat Metab Disord 1999;23:419-424.

8 Wake DJ,Walker BR: 11 beta-hydroxysteroid dehydrogenase type 1 in obesity and the metabolic syndrome. Mol Cell Endocrinol 2004;215:45-54.

- 9 Walker BR: Glucocorticoids and cardiovascular disease. Eur J Endocrinol 2007;157:545-559.

10 Walker BR: Cortisol - cause and cure for metabolic syndrome? Diabet Med 2006;23:1281-1288.

11 Masuzaki H, Paterson J, Shinyama H, Morton NM, Mullins JJ, Seckl JR, Flier JS: A transgenic model of visceral obesity and the metabolic syndrome. Science 2001;294:2166-2170.

12 Morton NM, Paterson JM, Masuzaki H, Holmes MC, Staels B, Fievet C, Walker BR, Flier JS, Mullins JJ, Seckl JR: Novel adipose tissue-mediated resistance to diet-induced visceral obesity in 11 beta-hydroxysteroid dehydrogenase type 1-deficient mice. Diabetes 2004;53:931-938.

13 Morton NM, Holmes MC, Fievet C, Staels B, Tailleux A, Mullins JJ, Seckl JR: Improved lipid and lipoprotein profile, hepatic insulin sensitivity, and glucose tolerance in 11beta-hydroxysteroid dehydrogenase type 1 null mice. J Biol Chem 2001;276:41293-41300. 
-14 Kotelevtsev Y, Holmes MC, Burchell A, Houston PM, Schmoll D, Jamieson P, Best R, Brown R, Edwards CR, Seckl JR, Mullins JJ: 11beta-hydroxysteroid dehydrogenase type 1 knockout mice show attenuated glucocorticoid-inducible responses and resist hyperglycemia on obesity or stress. Proc Natl Acad Sci U S A 1997; 94:14924-14929.

15 Veilleux A, Rheaume C, Daris M, Luu-The V, Tchernof A: Omental adipose tissue type 111 beta-hydroxysteroid dehydrogenase oxoreductase activity, body fat distribution, and metabolic alterations in women. J Clin Endocrinol Metab 2009;94:3550-3557.

-16 Baudrand R, Carvajal CA, Riquelme A, Morales M, Solis N, Pizarro M, Escalona A, Boza C, Perez G, Dominguez A, Arrese M, Fardella CE: Overexpression of 11beta-hydroxysteroid dehydrogenase type 1 in hepatic and visceral adipose tissue is associated with metabolic disorders in morbidly obese patients. Obes Surg 2010; 20:77-83.

17 Bamberger CM, Schulte HM, Chrousos GP: Molecular determinants of glucocorticoid receptor function and tissue sensitivity to glucocorticoids. Endocr Rev 1996;17:245-261.

18 Whorwood CB, Donovan SJ, Wood PJ, Phillips DI: Regulation of glucocorticoid receptor alpha and beta isoforms and type I 11beta-hydroxysteroid dehydrogenase expression in human skeletal muscle cells: a key role in the pathogenesis of insulin resistance? J Clin Endocrinol Metab 2001;86:2296-2308.

19 Michailidou Z, Jensen MD, Dumesic DA, Chapman KE, Seckl JR, Walker BR, Morton NM: Omental 11betahydroxysteroid dehydrogenase 1 correlates with fat cell size independently of obesity. Obesity (Silver Spring) 2007;15:1155-1163.

20 Veilleux A, Laberge PY, Morency J, Noel S, Luu-The V, Tchernof A: Expression of genes related to glucocorticoid action in human subcutaneous and omental adipose tissue. J Steroid Biochem Mol Biol 2010;122: 28-34.

21 Boullu-Ciocca S, Paulmyer-Lacroix O, Fina F, Ouafik L, Alessi MC, Oliver C, Grino M: Expression of the mRNAs coding for the glucocorticoid receptor isoforms in obesity. Obes Res 2003;11:925-929.

-22 Cornier MA, Dabelea D, Hernandez TL, Lindstrom RC, Steig AJ, Stob NR, Van Pelt RE, Wang H, Eckel RH: The metabolic syndrome. Endocr Rev 2008;29:777-822. Wallace TM, Levy JC, Matthews DR: Use and abuse of HOMA modeling. Diabetes Care 2004;27:1487-1495.

-24 Kannisto K, Pietilainen KH, Ehrenborg E, Rissanen A, Kaprio J, Hamsten A, Yki-Jarvinen H: Overexpression of 11beta-hydroxysteroid dehydrogenase- 1 in adipose tissue is associated with acquired obesity and features of insulin resistance: studies in young adult monozygotic twins. J Clin Endocrinol Metab 2004;89:4414-4421.

-25 Paulmyer-Lacroix O, Boullu S, Oliver C, Alessi MC, Grino M: Expression of the mRNA coding for 11betahydroxysteroid dehydrogenase type 1 in adipose tissue from obese patients: an in situ hybridization study. J Clin Endocrinol Metab 2002;87:2701-2705.

-26 Desbriere R, Vuaroqueaux V, Achard V, Boullu-Ciocca S, Labuhn M, Dutour A, Grino M: 11beta-hydroxysteroid dehydrogenase type $1 \mathrm{mRNA}$ is increased in both visceral and subcutaneous adipose tissue of obese patients. Obesity (Silver Spring) 2006;14:794-798.

-27 Paulsen SK, Pedersen SB, Fisker S, Richelsen B: 11Beta-HSD type 1 expression in human adipose tissue: impact of gender, obesity, and fat localization. Obesity (Silver Spring) 2007;15:1954-1960.

-28 Lee MJ, Fried SK, Mundt SS, Wang Y, Sullivan S, Stefanni A, Daugherty BL, Hermanowski-Vosatka A: Depotspecific regulation of the conversion of cortisone to cortisol in human adipose tissue. Obesity (Silver Spring) 2008;16:1178-1185.

29 Tomlinson JW, Sinha B, Bujalska I, Hewison M, Stewart PM:. Expression of 11beta-hydroxysteroid dehydrogenase type 1 in adipose tissue is not increased in human obesity. J Clin Endocrinol Metab 2002;87:56305635.

-30 Baudrand R, Dominguez JM, Carvajal CA, Riquelme A, Campino C, et al: Overexpression of hepatic $5 \alpha$-reductase and $11 \beta$-hydroxysteroid dehydrogenase type 1 in visceral adipose tissue is associated with hyperinsulinemia in morbidly obese patients. Metabolism 2011;60:1775-1780.

-31 Basu R, Singh RJ, Basu A, Chittilapilly EG, Johnson MC, Toffolo G, Cobelli C, Rizza RA: Obesity and type 2 diabetes do not alter splanchnic cortisol production in humans. J Clin Endocrinol Metab 2005;90:3919-3926

-32 Valsamakis G, Anwar A, Tomlinson JW, Shackleton CH, McTernan PG, Chetty R, Wood PJ, Banerjee AK, Holder G, Barnett AH, Stewart PM, Kumar S: 11beta-hydroxysteroid dehydrogenase type 1 activity in lean and obese males with type 2 diabetes mellitus. J Clin Endocrinol Metab 2004;89:4755-4761.

-33 Staab CA, Maser E: 11beta-hydroxysteroid dehydrogenase type 1 is an important regulator at the interface of obesity and inflammation. J Steroid Biochem Mol Biol 2010;119:56-72

-34 Handoko K, Yang K, Strutt B, Khalil W, Killinger D: Insulin attenuates the stimulatory effects of tumor necrosis factor alpha on 11beta-hyd roxysteroid dehydrogenase 1 in human adipose stromal cells. J Steroid Biochem Mol Biol 2000;72:163-168.

-35 Tomlinson JW, Finney J, Gay C, Hughes BA, Hughes SV, Stewart PM: Impaired glucose tolerance and insulin resistance are associated with increased adipose 11beta-hydroxysteroid dehydrogenase type 1 expression and elevated hepatic 5alpha-reductase activity. Diabetes 2008;57:2652-2660.

-36 Wake DJ, Rask E, Livingstone DE, Soderberg S, Olsson T, Walker BR: Local and systemic impact of transcriptional up-regulation of 11beta-hydroxysteroid dehydrogenase type 1 in adipose tissue in human obesity. J Clin Endocrinol Metab 2003;88:3983-3988.

-37 Chrousos GP, Kino T: Glucocorticoid signaling in the cell. Expanding clinical implications to complex human behavioral and somatic disorders. Ann N Y Acad Sci 2009;1179:153-166. 